\title{
The Influence of Germinated Grain Mix on the Quality of Extruded Fodder
}

\author{
Vasily V. Matyushev, Irina A. Chaplygina, Alexander V. Semenov, and Alexey A. Belyakov* \\ Krasnoyarsk State Agrarian University, 90, Mira Ave, Krasnoyarsk, 660049, Russia \\ *Corresponding author's Email: chaplygin-ia@kgau.ru; ORCID: 0000-0001-6695-0808
}

Received: 09 Apr 2021

Accepted: 20 May 2021

\begin{abstract}
The main factor in the development of modern animal husbandry is the development of methods for preparing feed for animals and enhancement of their nutritional value. To obtain high-energy feed, there is a need to use the germinated grain as one of the components for the extrusion used in animal food processing. The quality assessment of the extruded feed in terms of environmental and energy indicators based on a two-component mixture is of particular interest. In this regard, the purpose of the present research was to identify the regularities of changes in metabolic energy and the ecological-energy indicator of the feed quality, depending on the quantitative and qualitative content of the germinated component included in the extruded mixture. Wheat was mixed for 72 hours with pre-germinated grains of wheat, rapeseed, peas, oats, soybeans, or corn. The resulting mixture was extruded at a temperature of $120-130^{\circ} \mathrm{C}$ and pressure of $4-5 \mathrm{MPa}$. The highest metabolic energy of the feed was found in the extruded mixture containing $25 \%$ sprouted grains of soybeans, rapeseed, corn, peas, oats $15 \%$, and wheat $10 \%$. Regarding energy indicators, it is advisable to use $25 \%$ of the sprouted grain of soybeans, rapeseed, corn, peas, $15 \%$ of oats, and $10 \%$ of wheat in the extruded mixture as well as $10 \%$ of sprouted wheat, $25 \%$ peas, $25 \%$ corn, $10 \%$ soybeans, $20 \%$ oats, and $10 \%$ rapeseed. Based on the obtained results, a mathematical model was designed using the theory of splines. The modeling was carried out in the Maple package.
\end{abstract}

Keywords: Extrusion, Feed, Grain, Germination, Mix

\section{INTRODUCTION}

Much of the production cost in the livestock industry accounts for fodder $(65-75 \%)$. To increase the productivity of the animal ration, some fodder additives were administered and different ways of preparing fodder were examined (Shcheglov, 1990; Lukht, 2004; Matyushev et al., 2019). Grain and vegetable feed are the main components of animal diets. The share of grain included in compound feed accounts for up to 70 percent or more (Okolelova, 1999).

Fodder enrichment with biologically active substances that ensure high preservation of young animals, an increase in live weight, general resistance, and productivity of farm animals is possible due to the use of germinated grain, which has an increased amount of micronutrients and easily digestible forms of nutrients in its compositions (Sayfullin, 2017; Ali et al., 2019; Farghaly et al., 2019). There is a problem of unique fodder properties preservation during the grain germination and its further use, which can be solved by extruding a mixture while one of the components is germinated (Soder et al., 2018).

Despite the well-known publications (Sayfullin, 2017; Shvetsov et al., 2019), the regularities of changes in the quality of extruded feed depending on the quantitative and qualitative composition of the mixture is insufficiently studied. Research findings have established that feeding sprouted grain is an effective method of increasing the intensity of growth and development of young cattle (Peer and Leeson, 1985; Batrakov, 2012). Sprouted grain surpasses natural grain in protein content, essential amino acids, trace elements, vitamins $\mathrm{E}$, and group $\mathrm{B}$ (Podletskaya, 1980; Lardy, 2017).

Extrusion was carried out at a temperature of 120 $150^{\circ} \mathrm{C}$ and pressure of 4-5 $\mathrm{MPa}$, starch dextrinization occurs, the digestibility of feed increases because nutrients become more accessible to animals (Salazar-Villanea et al., 2018). Since the bar thermal effect increases in the process of extrusion, the sterilization of grain (i.e. barley, corn, wheat, bran, etc.) and the inactivation of toxic substances may occur (Kosolapov, 2018). Some authors 
noted the expediency of using extruded feeds with sprouted grain in animal diets in their works (Sofronov et al., 2017; Shvetsov et al., 2019). Sayfullin (2017) conducted a comparative assessment of the developed recipes for feed mixtures using wheat, barley, and corn grains, prepared for feeding by crushing, germination, and extrusion. The research results have shown that the most effective method is germination and the mixture extrusion. Compared with the crushing of the mixture, the proposed method has increased the profit and the level of profitability by $2.4-9.0 \%$ and $0.4-2.2 \%$, respectively (Sayfullin, 2017). Due to the improvement of the chemical composition of the feed mixture of pre-germinated rapeseed grain with subsequent extrusion, the average daily gains of calves increased by $9.8 \%$, compared with the use of only one extrusion (Sayfullin, 2017).

Studies on the pre-germinated grains of corn, wheat, and barley to the feed mixture have shown that the introduction of the obtained feed component into the feed ration of livestock has made it possible to increase the profitability of livestock production by $2.2 \%$ (Shvetsov et al., 2019).

The process of grain germination is influenced by the preliminary processing method (Chaplygina et al., 2020). The extruded feed is assessed by ecological and energy indicators based on a two-component mixture, one of which is germinated.
In this regard, the present research aimed to identify the patterns of changes in metabolic energy and the ecological-energy indicator of the feed quality depending on the quantitative and qualitative content of the germinated components included in the extruded mixture.

\section{MATERIALS AND METHODS}

\section{Ethical approval}

The Present experiment does not contain any studies with human participants or animals performed by any of the authors.

\section{Main process}

Studies to determine the regularity of changes in the quality of extruded feed depending on the properties of the initial mixture were carried out at the Engineering Center of the Federal State Budgetary Educational Institution of Higher Education of Krasnoyarsk State Agrarian University, Krasnoyarsk, Russia. The material for the research was the seeds of rapeseed Trapper B4 2018, peas Radamir Elita, wheat Novosibirskaya 15 Elita, corn Rosso140, soybean Zaryanitsa RS1, oats Sayan RS 3. They were provided from the educational sector in Sukhobuzimsky University district of the Krasnoyarsk Territory.

Table 1. The amount of germinated grain mixed with non-germinated wheat

\begin{tabular}{|c|c|c|c|c|c|c|c|}
\hline $\begin{array}{c}\text { Mix } \\
\text { № }\end{array}$ & $\begin{array}{l}\text { Wheat grain not } \\
\text { sprouted, } \%\end{array}$ & $\begin{array}{c}\text { Sprouted grains } \\
\text { wheat, } \%\end{array}$ & $\begin{array}{c}\text { Sprouted grains } \\
\text { rapeseed, } \%\end{array}$ & $\begin{array}{c}\text { Sprouted grains } \\
\text { peas, } \%\end{array}$ & $\begin{array}{c}\text { Sprouted } \\
\text { grains oats, \% }\end{array}$ & $\begin{array}{l}\text { Sprouted grains } \\
\text { soybeans, } \%\end{array}$ & $\begin{array}{c}\text { Sprouted } \\
\text { grains corn, \% }\end{array}$ \\
\hline 1 & 90 & 10 & - & - & - & - & - \\
\hline 2 & 85 & 15 & - & - & - & - & - \\
\hline 3 & 80 & 20 & - & - & - & - & - \\
\hline 4 & 75 & 25 & - & - & - & - & - \\
\hline 5 & 90 & - & 10 & - & - & - & - \\
\hline 6 & 85 & - & 15 & - & - & - & - \\
\hline 7 & 80 & - & 20 & - & - & - & - \\
\hline 8 & 75 & - & 25 & - & - & - & - \\
\hline 9 & 90 & - & - & 10 & - & - & - \\
\hline 10 & 85 & - & - & 15 & - & - & - \\
\hline 11 & 80 & - & - & 20 & - & - & - \\
\hline 12 & 75 & - & - & 25 & - & - & - \\
\hline 13 & 90 & - & - & - & 10 & - & - \\
\hline 14 & 85 & - & - & - & 15 & - & - \\
\hline 15 & 80 & - & - & - & 20 & - & - \\
\hline 16 & 75 & - & - & - & 25 & - & - \\
\hline 17 & 90 & - & - & - & - & 10 & - \\
\hline 18 & 85 & - & - & - & - & 15 & - \\
\hline 19 & 80 & - & - & - & - & 20 & - \\
\hline 20 & 75 & - & - & - & - & 25 & - \\
\hline 21 & 90 & - & - & - & - & - & 10 \\
\hline 22 & 85 & - & - & - & - & - & 15 \\
\hline 23 & 80 & - & - & - & - & - & 20 \\
\hline 24 & 75 & - & - & - & - & - & 25 \\
\hline
\end{tabular}


Wheat grain was used as the main component in the research. Before germination, the grains were subjected to a disinfection process (Chaplygina et al., 2020). Control grain samples with a layer of $20 \mathrm{~cm}$ were soaked and germinated in the water at a temperature of $20 \pm 1{ }^{\circ} \mathrm{C}$. Grain germination was carried out for 72 hours, taking into account the soaking time. Sprouted grains (wheat, rapeseed, peas, oats, soybeans, and corn) with sprouts and roots up to $2 \mathrm{~mm}$ were introduced into the mixtures in amounts of $10 \%, 15 \%, 20 \%$, and $25 \%$ (Table 1). Sprouted grains (wheat, rapeseed, peas, oats, soybeans, corn) with sprouts and roots up to $2 \mathrm{~mm}$ were introduced into the mixtures for extrusion. A total of 24 mixtures were obtained: with $10 \%, 15 \%, 20 \%$ and $25 \%$, germinated wheat, mixtures with $10 \%, 15 \%, 20 \%$, and $25 \%$ germinated rapeseed, with $10 \%, 15 \%, 20 \%$, and $25 \%$ sprouted peas, with $10 \%, 15 \%, 20 \%$, and $25 \%$ sprouted oats, with $10 \%, 15 \%, 20 \%$, and $25 \%$ sprouted soybeans and with $10 \%, 15 \%, 20 \%$, and $25 \%$ sprouted corn.. The prepared mixture was subjected to extrusion on an EK-100 extruder. The extrusion process began with the wheat grains extrusion. Upon reaching a temperature of 120$130^{\circ} \mathrm{C}$, the extrusion of experimental samples started. After extrusion, the prototypes were cooled and crushed.

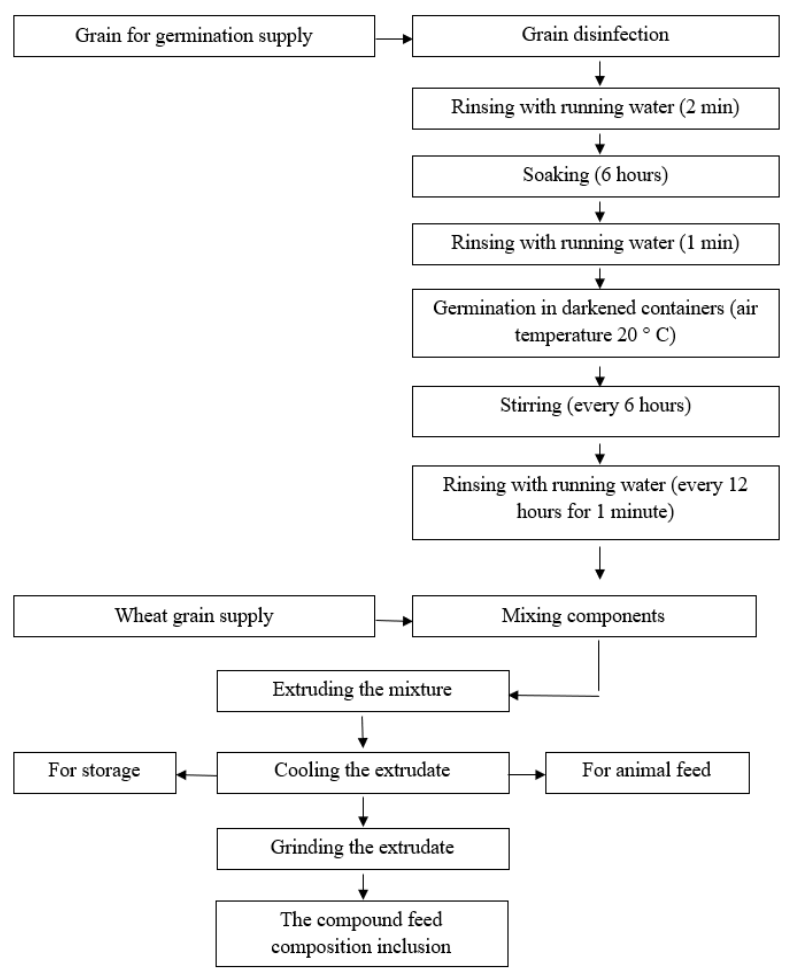

Figure 1. Scheme of extrudate productions with a preliminary germination as one of the components
The extrudates with pre-germination production is shown in Figure 1. The raw materials, prepared mixture, and extruded feed were investigated according to accredited methods at the research and development center Krasnoyarsk State Agrarian University, Federal state budgetary institution 'Krasnoyarsk Rosselkhoznadzor Reference Center' and Federal State Budgetary Institution Center of Agrochemical Service' (Krasnoyarsk, Russia).

The amount of metabolizable energy (W, Fat mass $/ \mathrm{kg}$ dry matter) determines the energy value of the finished product, and the ecological-energy indicator of product quality (E.) evaluates both the energy and environmental safety of the feed.

In this case, the environmental safety of feed is assessed through the concentration of heavy metals contained in the product and, in turn, determines the environmental safety coefficient (K). Therefore, the ecological and energy indicator of the quality of finished products is determined by the following formula:

$$
\mathrm{E}: \mathrm{W} \mathrm{K}
$$

(formula 1)

and the environmental safety factor is introduced as a weighted mean square:

$$
K=\sqrt{\sum_{i} p_{i}\left(1-\frac{m_{i}-\underline{m}_{i}}{\bar{m}_{i}}\right)^{2}},
$$

Where, $p_{i}>0$ refers to the weight coefficient of the i metal,

$$
\sum_{i} p_{i}=1 ; \quad \bar{m}_{i} \text { is the maximum permissible mass of }
$$
the $\mathrm{i}$ metal in the original product (majorant), ${ }^{m_{i}}$ denotes the mass of the i metal in the original product; and $\underline{m}_{i}$ signifies the minimum possible mass of the $i$ metal in the original product (background, minorant). If the content of heavy metals in the feed is minimal $\left(m_{i}=\underline{m}_{i}\right)$, then the environmental safety factor is equal to one (Tsuglenok, 2004).

\section{Statistical analysis}

A regression analysis of the data on the content of nutrients, heavy metals, and exchange energy in the extrudates was carried out using the DataFit analysis package. The data obtained were used to develop a mathematical model using the theory of splines. The modeling was carried out in the Maple package. 


\section{RESULTS}

With an increase in the mass fraction of germinated grain in the mixture before extrusion from 10 to $25 \%$, the exchange energy of the finished feed (Fat mass/kg dry matter) increased with the introduction of peas by 0.03 , soybeans by 0.02 , corn by 0.61 , rapeseed by 0.2 and decreased with the introduction of wheat by 0.38 and oats by 0.2 .
Moreover, with an increase in sprouted oats in the mixture to $15 \%$, the exchange energy of the extruded feed increased to 12.84 Fat mass $/ \mathrm{kg}$ dry matter, and with a further increase in the mass fraction of oats, the extrusion process was unstable, and the exchange energy decreased. The maximum values of the exchange energy depending on the quantitative and qualitative composition of the mixture with the inclusion of germinated grain are presented in Figure 2.

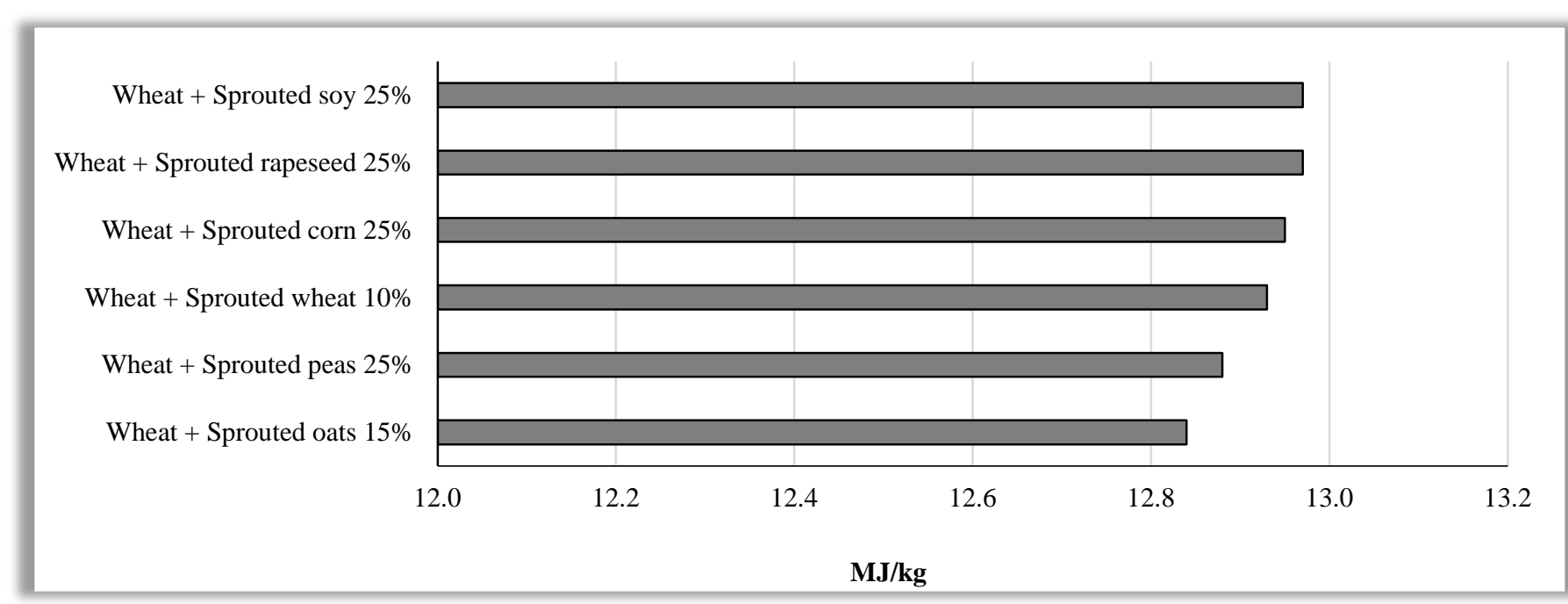

Figure 2. The maximum value of the exchange energy of the extruded feed, depending on the quantitative and qualitative composition of the mixture with the inclusion of sprouted grains

At the preliminary level of research, a statistical analysis of the experimental values of general and particular indicators of the quality of grain feed was carried out. For the main research, the authors obtained model representations of these indicators depending on the biochemical composition of the sample developed an analytical model and an application program in the Maple language.

It was found that the value of exchange energy (W, Fat mass $/ \mathrm{kg})$ depending on protein $\left(\mathrm{x}_{1}, \%\right)$, fat $\left(\mathrm{x}_{2}, \%\right)$, fiber $\left(\mathrm{x}_{3}, \%\right)$, ash $\left(\mathrm{x}_{4}, \%\right)$, starch $\left(\mathrm{x}_{5}, \%\right)$, sugar $\left(\mathrm{x}_{6}, \%\right)$, as well as the content of carotene $\left(\mathrm{x}_{7}, \mathrm{mg} / \mathrm{kg}\right)$, phosphorus $\left(\mathrm{x}_{8}, \%\right)$ and calcium $\left(\mathrm{x}_{9}, \mathrm{mg} / \mathrm{kg}\right)$ can be measured by function 1:

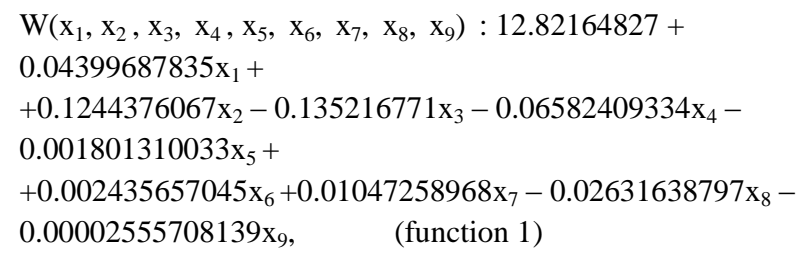

The coefficients identified both the positive (+) and negative (-) effects of the biochemical composition on the studied indicator of exchange energy. The content of heavy metals ( $\mathrm{K}$, units) depending on protein $\left(\mathrm{x}_{1}, \%\right)$, fat $\left(\mathrm{x}_{2}, \%\right)$, fiber $\left(\mathrm{x}_{3}, \%\right)$, ash $\left(\mathrm{x}_{4}, \%\right)$, starch $\left(\mathrm{x}_{5}, \%\right)$, sugar $\left(\mathrm{x}_{6}, \%\right)$, as well as the content of carotene $\left(\mathrm{x}_{7}, \mathrm{mg} / \mathrm{kg}\right)$, phosphorus $\left(\mathrm{x}_{8}, \%\right)$ and calcium $\left(\mathrm{x}_{9}, \mathrm{mg} / \mathrm{kg}\right)$ is represented by the function 2 :

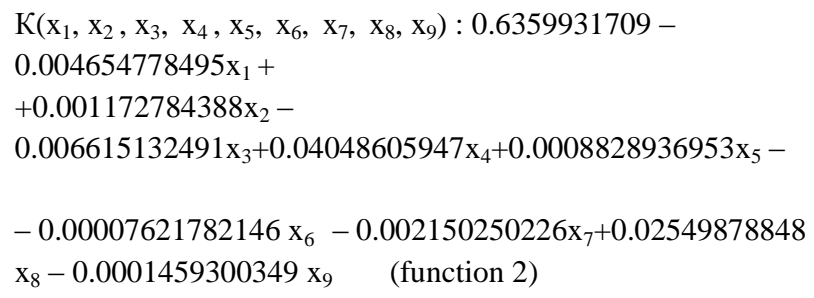

The coefficients identified the influence of the biochemical composition on the investigated indicator of the heavy metal content. With an increase in the mass fraction of germinated grain in the mixture before extrusion from 10 to $25 \%$, the ecological-energy indicator 
of the quality of the finished feed (Fat mass/kg dry matter) increased with the introduction of peas, corn, and oats by $1.34,0.96$, and 0.34 , respectively, and decreased with the introduction of rapeseed by 1.44 , wheat by 0.43 , and soybeans by 0.38 . The maximum value of the ecologicalenergy indicator of the extruded feed quality, depending on the quantitative and qualitative composition of the mixture with the germinated grain, is presented in Figure 3.

The value of the ecological-energy index (E, fat mass / $\mathrm{kg})$ depending on protein $\left(\mathrm{x}_{1}, \%\right)$, fat $\left(\mathrm{x}_{2}, \%\right)$, fiber $\left(\mathrm{x}_{3}, \%\right)$, ash $\left(\mathrm{x}_{4}, \%\right)$, starch $\left(\mathrm{x}_{5}, \%\right)$, sugar $\left(\mathrm{x}_{6}, \%\right)$, as well as the content of carotene $\left(\mathrm{x}_{7}, \mathrm{mg} / \mathrm{kg}\right)$, phosphorus $\left(\mathrm{x}_{8}, \%\right)$ and calcium $\left(\mathrm{x}_{9}, \mathrm{mg} / \mathrm{kg}\right)$ is represented by the following function 3:

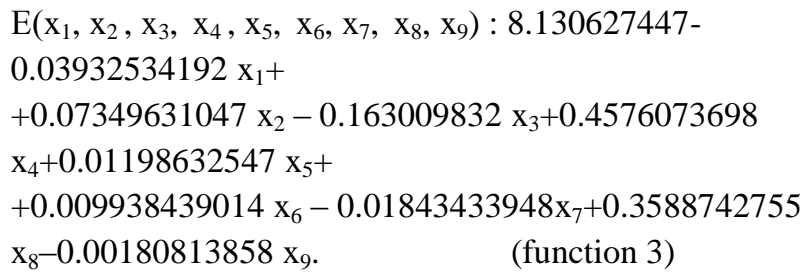

The research results indicated a change in the quality of extruded feed depending on the quantitative and qualitative composition of the mixture (one of the components was germinated).

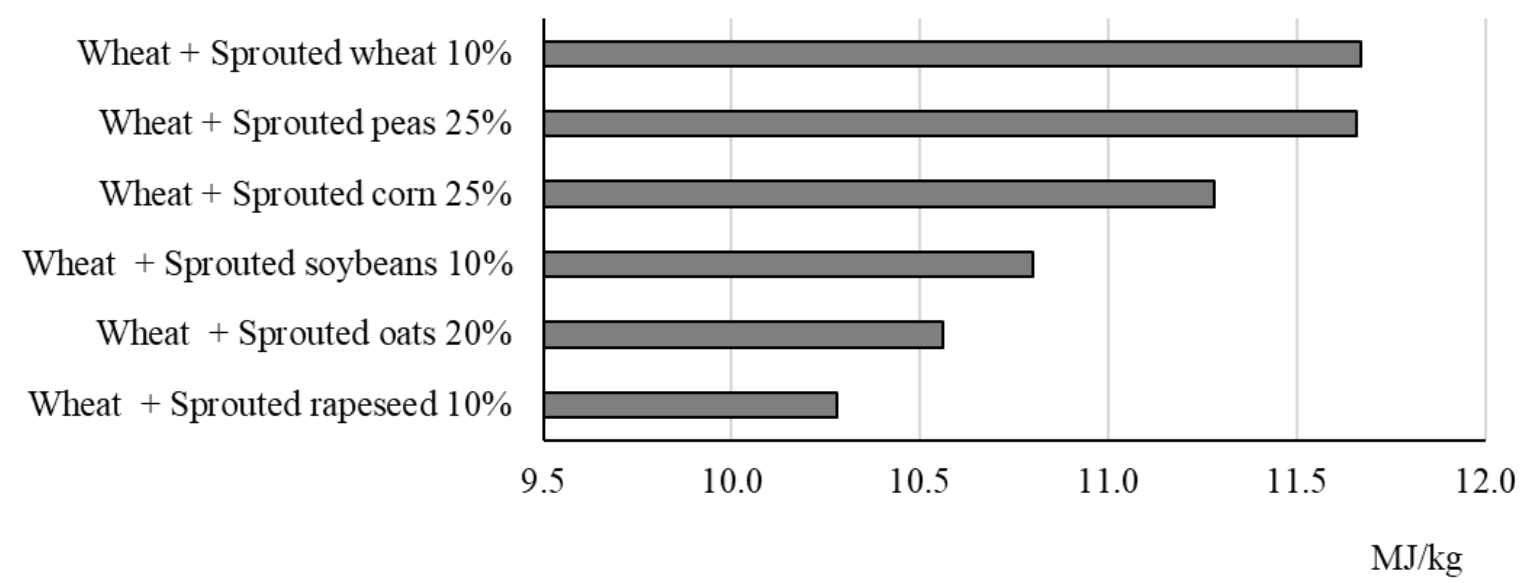

Figure 3. The maximum value of the ecological-energy indicator of the extruded feed quality depending on the quantitative and qualitative composition of the mixture with the germinated grains

\section{DISCUSSION}

The exchange energy of the finished extruded feed varied depending on the seedlings used in the mixture and their quantity. According to the data obtained, an increase in the proportion of sprouted grain in the mixture was revealed up to $25 \%$ using soybeans, peas, rapeseed, and corn led to an increase in the content of metabolic energy in feed. When using sprouted wheat, an inverse relationship was observed, meaning that the amount of exchange energy decreased with an increase in the proportion of germinated grain in the mixture. The use of germinated oat grain of more than $15 \%$ is not advisable, as it leads to an instability of the extrusion process under the given conditions.

Based on the research data on energy indicators, it is advisable to use $25 \%$ of a sprouted grain of soybeans, rapeseed, corn, peas, $15 \%$ oats, or $10 \%$ wheat in the extruded mixture as one of the components.
This content of sprouted grain in the mixture could be recommended for practical use in agricultural production, but an assessment of not only the nutritional value but also the safety of feed is required. It is advisable to carry out a comprehensive assessment using the ecological and energy quality index of the extruded mixture. Data analysis on the content of heavy metals in seedlings grain suggested that their total quantity increased and decreased, respectively.

The largest total amount of heavy metals was noted in rapeseed, the minimum in wheat. Accordingly, in rapeseed, the minimum value of the ecological-energy indicator $\mathrm{K}$. The ability of rape seedlings to accumulate heavy metals was previously noted in other studies (Radionov et al., 2007).

The ecological and energy indicator of the extruded feed quality containing sprouted rape Data analysis on the content of heavy metals in seedlings grain suggests that their total quantity increases and decreases respectively in 
the row $\mathrm{K}$ wheat $<$ peas $<$ corn-soy $<<$ oats $<$ canola. The ability of rape seedlings to accumulate heavy metals was previously noted in other studies had the lowest value (Radionov et al., 2007). The greatest value was noted when using pea seedlings in a mixture.

The analytical model and the applied program obtained based on the research results allow predicting the content of exchange energy, heavy metals, and the value of the ecological-energy index of the extruded mixture, one of the components of which is germinated, depending on the biochemical composition of the feed. The convergence of the experimental and calculated data on the ecological and energy index ranged from $92 \%$ to $96 \%$.

Thus, to obtain ecologically safe livestock products, it is reasonable to use an extruded mixture in the animal diet, containing sprouted grains as one of the components with a high ecological and energy index of feed quality.

\section{CONCLUSION}

Using the methods of a natural and computational experiment with an analytical model and an applied Maple-program, it can be concluded that it is rational to use sprouted grain as one of the components of an extruded mixture in the diet of animals to obtain ecologically safe livestock products in various natural and ecological conditions.

To obtain feed with the highest ecological and energy quality indicators, it is advisable to use one of the proposed germinated components in the amount of $10 \%$ wheat, $25 \%$ peas, $25 \%$ corn, $10 \%$ soybeans, $20 \%$ oats, or $10 \%$ rapeseed. The ecological and energy indicator of the quality of extruded feed containing sprouted rape had the least value. The greatest value was noted when using wheat or pea seedlings in a mixture.

\section{Acknowledgments}

The research was funded by the Ministry of Agriculture of Russia 'Innovative methods of preparing grain feeds processed by extrusion with preliminary germination of one of the components to use in cattle breeding.

\section{Authors' contributions}

The authors carried out the formulation of problems, germination of grain, development of formulations of mixtures, obtaining extrudates, data analysis, statistical processing, and the development of a mathematical model. V.V. Matyushev carried out the setting of tasks and planning of the experiment, germination of grain, extrusion of mixtures, and analysis of research results. Chaplygina I.A. carried out the planning of the experiment, germination of grain, extrusion of mixtures, analysis of research results. Semenov A.A. carried out the germination of grain and the extrusion of mixtures.

A. A. Belyakov carried out mathematical processing and construction of a mathematical model.

\section{Competing interests}

The authors declare no conflicts of interest.

\section{Ethical considerations}

All ethical issues (Including plagiarism, consent to publish, misconduct, data fabrication and/or falsification, double publication and/or submission, and redundancy) have been checked by the authors.

\section{REFERENCES}

Ali H, Miah A, Sabuz S, Asaduzzaman M, and Salma U (2019). Dietary effects of hydroponic wheat sprouted fodder on growth performance of turkey. Research in Agriculture Livestock and Fisheries, 6(1): 101-110. DOI: https://www.doi.org/10.3329/ralf.v6i1.41392

Batrakov AY (2012). The influence of germinated grain on the metabolism of calves. Veterinary Medicine, 1: 46-47. Available at: https://www.elibrary.ru/item.asp?id=17663437

Chaplygina IA, Matyushev VV, Shanina EV, Semenov AV, and Shmeleva ZhN (2020). The development of technological parameters of seed sprouting before extrusion. III International scientific conference: AGRITECH-III-2020: Agribusiness, Environmental Engineering and Biotechnologies. Krasnoyarsk Science and Technology City Hall of the Russian Union of Scientific and Engineering Associations, 548(4): $42067 . \quad$ DOI: https://www.doi.org/10.1088/1755-1315/548/4/042067

Farghaly MM, Abdullah MAM, Youssef IMI, Abdel-Rahim IR, and Abouelezz K (2019). Effect of feeding hydroponic barley sprouts to sheep on feed intake, nutrient digestibility, nitrogen retention, rumen fermentation and ruminal enzymes activity. Livestock Science, 228: 31-37. DOI: https://www.doi.org/10.1016/j.livsci.2019.07.022

Kosolapov VM (2018). Technological foundations for improving the quality of feed: Practical recommendations. LLC Ugreshskaya Printing House, Moscow, p. 52. Available at: http://elib.cnshb.ru/books/free/0388/388175/files/assets/basi c-html/page-1.html\#

Lardy G (2017). Feeding value of sprouted grains. Livestock, pp. 1-6. Available at: https://www.ag.ndsu.edu/publications/livestock/feedingvalue-of-sprouted-grains

Lukht HV (2004). Peas in animal feeding. Animal Husbandry of Russia, 9: 24-33.

Matyushev VV, Chaplygina IA, Semenov AV, Shanina EV, and Shmeleva ZhN (2019). Method of increasing the mixed 
fodder nutritional and energy value. IOP Conference Agribusiness, Environmental Engineering and Biotechnologies, 421: 62033 DOI: https://www.doi.org/10.1088/1755-1315/421/6/062033

Okolelova TM (1999). Increasing the value of grain germination. Compound Feed, 2: 36-37. Available at: https://www.elibrary.ru/item.asp?id=24877482

Peer DJ, and Leeson S (1985). Feeding value of hydroponically sprouted barley for poultry and pigs. Animal Feed Science and Technology, 13: 183-190. DOI: https://www.doi.org/10.1016/0377-8401(85)90022-7

Podletskaya HH (1980). Influence of the level of vitamin nutrition on the metabolism of trace elements in young pigs. Reports of the All-Union Academy of Agricultural Sciences named after Lenin, 1: 25-27. Available at: https://agris.fao.org/agrissearch/search.do?recordID $=$ SU19800541676

Radionov NV, Volkov KS, and Kholodova VP (2007). Comparative analysis of the resistance of rape plants to high concentrations of copper and zinc. Bulletin of the Russian University of Friendship of Peoples. Series: Agronomy and Livestock, 4: 21-29. Available at: https://cyberleninka.ru/article/n/sravnitelnyy-analizustoychivosti-rasteniy-rapsa-k-povyshennymkontsentratsiyam-medi-i-tsinka/viewer

Salazar-Villanea S, Bruininx E, Gruppen H, Hendriks W, Carré P, Quinsac A, and Van der Poel A (2018). Pelleting and extrusion can ameliorate negative effects of toasting of rapeseed meal on protein digestibility in growing pigs. Animal, 12(5): 950-958. DOI: https://www.doi.org/10.1017/S1751731117002476
Sayfullin AS (2017). Zohygienic substantiation of the use of extruded feed in feeding calves. Scientific notes of the Kazan State Academy of Veterinary Medicine named after N.E. Bauman, 230(2): 121-125. Available at: https://cyberleninka.ru/article/n/zoogigienicheskoeobosnovanie-ispolzovaniya-ekstrudirovannogo-korma-vkormlenii-telyat/viewer

Shcheglov VV (1990). Feed: Preparation, storage, use: Reference book. Agropromizdat, Moscow, p. 255.

Shvetsov N, Kotarev V, Kovrigin A, and Shvetsova M (2019). Effect of Sprouted and Extruded Grain in Composition of Fodder Mixtures on Digestibility of Dairy Cows Diet Nutrients, $\quad 1$ : $347-352$ DOI: https://www.doi.org/10.2991/isils-19.2019.68

Soder KJ, Heins BJ, Chester-Jones H, Hafla AN, and Rubano MD (2018). Evaluation of fodder production systems for organic dairy farms. The Professional Animal Scientist., 34(1): 75-83. DOI: https://www.doi.org/10.15232/pas.2017$\underline{01676}$

Sofronov VG, Danilova NI, Yamaev EI, Kuznetsova EL, and Sofronov PV (2017). Influence of ex-labor feed on the indicators of protein metabolism in calves. Prospects for the development of modern agricultural sciences. Collection of scientific papers on the basis of the international scientific and practical conference. Veterinary of Agricultural Animals, 4: 22-25. Available at: https://www.elibrary.ru/item.asp?id=36995813

Tsuglenok NV (2004). Mathematical model of energy productivity in fodder production. Bulletin of the Krasnoyarsk State Agrarian University, 6: 3-12. Available at: https://www.elibrary.ru/item.asp?id=42503062 